\title{
Drug Use, Homelessness and Health: Responding to The Opioid Overdose Crisis with Housing First Models
}

Katrina Milaney ( $\boldsymbol{\sim}$ katrina.milaney@ucalgary.ca )

University of Calgary https://orcid.org/0000-0003-4761-589X

Jenna Passi

University of Calgary

Lisa Zaretsky

University of calgary

Tong Liu

Dalhousie University

Claire M O'Gorman

Alberta Health Services

Leslie Hill

HIV Community Link

Daniel Dutton

Dalhousie University

Research

Keywords: opioids, homelessness, harm reduction, hospital use

Posted Date: October 30th, 2020

DOl: https://doi.org/10.21203/rs.3.rs-97739/v1

License: (c) (i) This work is licensed under a Creative Commons Attribution 4.0 International License.

Read Full License 
1 Drug Use, Homelessness and Health: Responding to the Opioid Overdose Crisis with

$2 \quad$ Housing First Models

3 Abstract

4

5

6

7

8

Background: Canada is in the midst of an opioid overdose crisis and Alberta has one of the highest opioid use rates across the country. Populations made vulnerable through structural inequities who also use opioids, such as those who are unstably housed, are at an increased risk of experiencing harms associated with opioid use. The main purpose of this study was to explore if there was an association between unstable housing and hospital use for people who use opioids. Methods: Analysis utilized self-reported data from the Alberta Health and Drug Use Survey which surveyed 813 Albertans in three cities. Hospital use was modeled using a logistic regression with our primary variable of interest being housing unstable status. Chi square tests were conducted between hospital use and variables associated with demographics, characteristics of drug use, health characteristics, and experiences of receiving services to establish model inclusion. Results: Results revealed a significant association between housing instability and hospital use, with unstably housed individuals twice as likely to become hospital users. Conclusions: Results highlight the importance of concurrently addressing housing instability alongside the provision of harm reduction services such as Housing First programs and supervised consumption sites. These findings have significant implications for policy and policymakers during the opioid overdose epidemic, and provide a foundation for future areas of research.

Keywords: opioids; homelessness; harm reduction; hospital use 


\section{Background}

Canada is currently experiencing a national opioid overdose crisis. Since January 2016,

25 there have been over 15,300 apparent opioid-related deaths across Canada with over 19,300

26 hospitalizations due to opioid-related poisonings (Government of Canada, 2020). Between 2013

27 and 2018, hospitalizations related to opioid poisonings across Canada increased by $27 \%$, while

28 rates of hospitalization and emergency department visits continue to rise (CIHI, 2018). The

29 Government of Canada has taken important steps to support individuals who use opioids across

30 the country by increasing access to treatment, expanding awareness and prevention of opioid-

31 related harms, supporting data collection and research, increasing access to harm reduction

32 strategies such as supervised consumption sites, and working to decrease the tainted drug supply

33 (Government of Canada, 2020).

Alberta continues to have some of the highest rates of opioid-related deaths, emergency department visits, and hospitalizations within Canada. In Alberta, 2,667 individuals died from an accidental opioid poisoning since January 1, 2016, with over 140 deaths already reported in the

37 first three months of 2020 (Government of Alberta, 2020a; Government of Alberta, 2020b).

38 Emergency department visits related to opioids and other drug use increased $41 \%$ between

39 January 1, 2016 and the third quarter of 2019, while hospitalizations related to opioids and other 40 drug use increased 19\% between January 1, 2016 and the third quarter of 2019 (Government of 41 Alberta, 2020b). In the last quarter of 2019, Alberta reported over 2,470 emergency and urgent

42 care visits associated with opioids and other drug use, with $13 \%$ of individuals visiting more than once (Government of Alberta, 2020b). Although opioid-related deaths, emergency department

44 visits, and hospitalizations are reported at a broad level, there is a lack of publicly available 
45 demographic data. Specifically, there is no government-based reporting on opioid use or overdoses specific to individuals who are unstably housed.

According to the National Health Care for the Homeless Council (NHCHC), housing is a crucial social determinant of health and a lack of housing, or being unstably housed, is associated with mental health concerns, physical health problems, trauma, greater mortality rates, and substance use disorders (NHCHC, 2017). Individuals who are unstably housed are at an increased risk of experiencing opioid use and overdose. For example, Yamamoto et al. (2019) found a significantly higher risk of opioid overdose in those who were homeless than those who were housed. Similarly, a study by Doran et al. (2018) revealed a significant association between homelessness and opioid overdose. Results from other studies suggest overdose is the leading cause of mortality in the homeless population with rates up to 17 times higher than the general population (Baggett et al., 2013; Baggett et al., 2015). In British Columbia, a 2017 report revealed almost $30 \%$ of individuals who experienced an overdose reported unstable housing, and those with no fixed address were at a higher risk of experiencing repeated overdoses (BC Center for Disease Control, 2017). Finally, Zivanovic et al. (2015) found that unstable housing was independently associated with increased mortality rates, suggesting housing status is an important risk factor to be considered among individuals that use drugs. Thus, there is evidence to suggest there is an association between unstable housing and opioid-related harms.

Individuals who are unstably housed and use opioids often lack access to safe, adequate healthcare and are overrepresented in mental health concerns including substance use, anxiety, and depression (Magwood et al., 2020; Amari et al., 2011; Latimer et al., 2017). Results from some studies suggest housing instability is associated with higher unmet needs and lower rates of access to a family doctor, resulting in significantly more hospitalizations and visits to emergency 
69 housing instability and a lack of healthcare impact the individual experiencing inequities, the

70 economic impacts are substantial. In 2013, homelessness was estimated to cost the Canadian

71 economy more than $\$ 7$ billion annually including costs associated with healthcare services

72 (Gaetz et al., 2013). Furthermore, Latimer et al. (2017) examined the costs associated with

73 housing homeless individuals with mental health concerns across five Canadian cities and found

74 the average annual cost ranged between approximately $\$ 29,000$ and $\$ 56,000$ per person. These

75 authors argue that for every $\$ 1$ invested in housing and individualized case managed supports,

76 resulted in an average savings of just over $\$ 2$ in public costs.

To build upon the knowledge surrounding the importance of housing as a critical social

78 determinant of health within the opioid epidemic, the purpose of this study was to examine if

79 housing instability was associated with an increased likelihood of accessing hospital services for

80 problems with emotions, mental health, or alcohol/ drug use with additional variables of interest

81 including demographics, drug use characteristics, health characteristics, and/or experiences

82 receiving services.

\section{Methods}

\section{$84 \quad$ Participants}

85 We utilized self-reported data from the Alberta Health and Drug Use Survey results

86 (Alberta Health and Drug Use Survey, 2017 which surveyed 813 Albertans in three cities,

87 Calgary, Red Deer and Medicine Hat. Participants were recruited through local coalitions of 88 service providers in those cities. Information was collected on: 1) socio-demographics, drug use

89 and health; 2) drug use, risk behaviours, and experience of harm; 3) outcomes related to health

90 status, health service use, and unmet healthcare needs; and 4) acceptability of potential new 
91 health services. For the purposes of the current study, the total analytic sample was 432

92 participants and included those participants who: 1) reported using opioids via injection or non-

93 injection within the six-month period prior to participating in the Alberta Health and Drug Use

94 Survey (carfentanil, china white, codeine, demerol, fentanyl, heroin, hydrocodone,

95 hydromorphone, methadone, morphine, oxycodone, oxycontin, oxyneo, percocet, speed balls,

96 street methadone, and talwin); and 2) provided a true response (i.e., not 'Refused' or 'Don't

97 Know') to questions within the variables of interest for the current study including hospital use,

98 demographics, characteristics of drug use, health characteristics, and experiences receiving

99 services. Ethics approval was obtained through the University of Calgary Conjoint Health

100 Research Ethics Board REB:

101

102

$103 \quad$ Insert Table 1

104 Procedure

105 Data was analyzed using Stata. Hospital use was modeled using a logistic regression with 106 our primary variable of interest being housing unstable status. Chi-squared tests were conducted

107 between hospital use and potential confounders.. All demographic variables were included in our

108 final model. Variables regarding characteristics of drug use, health characteristics, and

109 experiences receiving services were included if they met a relaxed significance value $(\mathrm{p} \leq 0.1)$

110 and had variance inflation factors (VIF) scores below 2.5 when tested for multicollinearity

111 between independent variables (in a logistic regression on hospital use, not reported). Testing for

112 multicollinearity was conducted due to the multiple variables measuring drug use characteristics.

113 Variables with the highest p-values were removed from the model until the coefficients from the 
114 initial model showed a change larger than 20\%, which constituted our threshold for confounding. 115 At this point, all variables were left in the model and were considered confounders.

Once the final set of variables was established, interaction effects were tested for

117 between demographics and other explanatory variables, only keeping the significant interactions.

118 The adjusted model contained a single significant interaction effect: sex and diagnosis with

119 addiction or a mental health disorder.

120 Results

121 Sample Characteristics by Hospital Use with Pearson Chi-Squared Results

122

123

124

125

126

127

128

129

130

131

132

133

134

135

136
Table 2 presents sample characteristics by hospital use and results from the chi-squared tests assessing the association between hospital use and demographics, characteristics of drug use, health characteristics, and experiences receiving services.

Of the 432 participants, the majority were unstably housed (55.6\%), male (65.3\%), nonIndigenous (67.4\%), and had an average age of 37.4 years (range between $16-68$ ). Regarding hospital use, $42.4 \%$ of participants reported using hospital care (overnight or longer) within the six months prior to being surveyed. Among those that reported using hospital care, $67.8 \%$ of participants indicated unstable housing compared to those that did not use the hospital where only $46.6 \%$ indicated unstable housing. When looking at location and hospital use, hospital users were more likely to be in Medicine Hat or Red Deer (53.6\%).

Of the 432 participants, $31.7 \%$ had reported an overdose within the six months prior to taking part in the survey, $53.9 \%$ of participants reported using drugs $2-3 x$ per week or more, and $77.1 \%$ reported being heavily influenced by drugs weekly or daily. Chi-squared test results revealed multiple significant associations between participants who reported hospital use and characteristics of drug use such as overdosing $(\mathrm{p}=<0.001)$, frequently neglecting other tasks due 
137 to use ( $\mathrm{p}=<0.001)$, frequently needing to use in mornings after heavy usage the night before $138(\mathrm{p}=0.004)$, frequent polydrug use $(\mathrm{p}=0.003)$, frequently being heavily influenced by drugs $(\mathrm{p}=$ 139 0.011), others noting they are worried about the participants use $(\mathrm{p}=0.004)$, frequently feeling 140 an irresistible longing to use $(\mathrm{p}=0.038)$, frequently feeling guilty due to drug use $(\mathrm{p}=0.023)$, 141 and believing that themselves or others have been hurt due to their use $(\mathrm{p}=0.040)$. In contrast, 142 participants without these higher risk drug use characteristics were proportionally less likely to 143 report hospital use.

144 Of the 432 participants, $81.2 \%$ of participants reported being diagnosed with an addiction 145 or mental health disorder. Chi-squared test results revealed a significant association between 146 diagnosis with addiction or mental health concern and higher likelihood of hospital use $(\mathrm{p}=$ $1470.001)$.

Of the 432 participants, $55.1 \%$ of participants reported they were unable to access a type

149 of service they felt they needed. Chi-squared test results revealed a significant association 150 between hospital use and more unmet needs due to not having access to needed services $(\mathrm{p}=$ 151 0.017). 56.9\% of participants reported they were unable to access enough services they felt they 152 needed. 
Insert Table 2.

\section{Logistic Regression of Hospital Use}

Table 3 reports the results from the logistic regression on unadjusted and adjusted models, including an interaction term accounted for in the adjusted results. In the fully adjusted model, participants who reported unstable housing (OR:2.04, 95\% CI:1.29-3.21), an overdose (OR:3.59, 95\% CI:2.21-5.83), and neglecting tasks due to drug use on a frequent basis (weekly or more) (OR:2.19, 95\% CI:1.28-3.73) remained independently significant with a positive association. After testing for interaction effects between variables, the primary variable of interest for unstable housing did not have any significant interactions with the other variables contained in the model. Therefore, while controlling for all other variables in the model, those who were unstably housed were twice as likely to become hospital users.

The interaction effect between sex and having been diagnosed by a professional with an addiction and/or a mental health concern was significant. Among males, the effect of diagnosed status is insignificant and has minimal impact on hospital use; however, among females, those who had a diagnosis of an addiction and/or mental health concern from a professional were 28 times more likely to use the hospital (OR for females with a diagnosis = $\exp ($ interaction $) * \exp ($ diagnosis $)=(22.443) *(1.261)=28.26)$ than their counterparts. These results indicate that while controlling for all other factors within the model, the effect of diagnosis for addiction and/or mental health concerns among males is minimal or negligible in relation to hospital utilization. In contrast to this, diagnosed status among females has a significant and notable reaction on hospital use.

\section{Insert Table 3.}




\section{Discussion}

The main purpose of this study was to examine if housing instability was associated with an increased likelihood to access hospital services for problems with emotions, mental health, or alcohol/ drug use specifically amongst individuals who use opioids. Additional variables of interest included demographics, drug use characteristics, health characteristics, and/or experiences receiving services.

Results revealed that being unstably housed was associated with hospital use even after accounting for the additional variables. This finding is similar to previous studies that have found an association between unstable housing and increased utilization of hospital services (Magwood et al., 2020; Khandor et al., 2011; Jaworsky et al., 2016; Hwang et al., 2013).

Housing is considered a crucial social determinant of health and a lack of housing can have serious consequences on the health of homeless individuals. Homelessness has been associated with high mortality rates, extreme poverty, poor oral and dental health, and chronic conditions such as diabetes, seizures, respiratory problems, tuberculosis (TB), Human Immunodeficiency Virus (HIV), and widespread issues with alcohol and drugs (Hwang, 2001). Our findings support the growing evidence base highlighting the importance of housing and recovery-oriented models such as Housing First (Gaetz et al. 2013b). Housing First models are rooted in the belief that housing, not compliance or sobriety, is the foundation for recovery and once housing has been secured, a person can successfully address other areas in their life such as physical health, mental health, substance use, employment, and education (Gaetz et al. 2013b). Housing First models are based on five principles that: 1) allow individuals to access permanent housing with no requirements or conditions; 2) emphasize individual choice and self-determination; 3) focus on recovery within a harm reduction approach; 4) recognize the uniqueness of each individual and 
their needs once housing is secured; and 5) support individuals to integrate into their community with social supports (Gaetz et al. 2013b). Not only does securing housing increase the physical health and wellness of the unstably housed individual, studies show Housing First reduces hospitalizations and emergency department visits, thereby decreasing the economic costs associated with homelessness (Gaetz et al. 2013b).

As Magwood et al. (2020) purport, homeless individuals with substance use issues benefit from harm reduction strategies, including Housing First, by improving access to care, reducing opioid overdoses, and preventing or limiting the spread of infectious disease and other chronic conditions. Housing First is particularly important for individuals who are using opioids as they are high risk for overdose. Results from a study of people who use opioids who accessed a Housing First program showed a 93\% housing retention rate and $100 \%$ of participants accessed overdose prevention education and naloxone while in the program (Katzenstein et al, 2019).

Future studies could explore the difference in hospitalizations and emergency department visits for individuals who use opioids and are unstably housed and those in Housing First programs to determine if there is a significant difference between the two groups.

Although the Government of Canada has advocated and approved of harm reduction strategies and over 40 supervised consumption sites nationwide, the current Government of Alberta has halted funding for new supervised consumption sites as of summer 2019, citing socio-economic concerns. Supervised consumption sites provide a monitored environment for individuals who use substances and offer support services such as counselling, social work, and other opioid-dependency treatment options while reducing the transmission of infections and diseases and lowering the risk of overdose (AHS, 2016). The Calgary supervised consumption site responded to over 1,800 overdoses between October 30, 2017 and May 31, 2020 and 
231 received over 151,000 client visits during this time (AHS, 2020). A recent study by Jackson

232 showed that each overdose managed at the Calgary supervised consumption clinic saved

233 approximately $\$ 1,600$ per overdose or over $\$ 2.3$ million in total emergency health costs since the

234 site opened. Future studies could examine if moving from a harm reduction approach to an

235 abstinence-based approach has resulted in a change in hospitalization and emergency department

236 visits and subsequent costs.

237 Interestingly, results revealed a significant interaction between sex and having a mental

238 health and/or addiction diagnosis with regard to hospital use. Females who had a mental health

239 and/or addiction diagnosis were 28 times more likely to use the hospital than undiagnosed

240 females, a relationship 22 times higher than the same one in males, suggesting that males and

241 females vary in their likelihood of hospital usage based on if they have received a diagnosis. This

242 indicates that among opioid users who use hospital services, there is an important interplay

243 between females and status of professional diagnoses for addiction and/or mental health. Future

244 research could examine the sex differences associated with opioid use, hospital use and mental

245 health and/or addiction diagnoses to determine how to best to support varied subpopulations.

246 Limitations

247 This analysis had several limitations that should be taken into consideration. Self-report

248 measures are subject to bias and open to interpretation by participants. Since the Alberta Health

249 and Drug Use Survey focused on collecting survey data from individuals actively accessing

250 services and agencies, individuals that were not actively accessing services were not captured

251 within this analysis resulting in a potentially non-representative sample. Similarly, previous

252 research suggests homelessness has been associated with a lower likelihood of seeking treatment,

253 which could also indicate a nuanced subset not covered within this analysis (Galea et al., 2004). 
254 The analytic sample may not be generalizable because participants were excluded from the

255 analytic sample if they: 1) did not identify as either male or female due to low representation of

256 non-binary participants among the collected surveys; 2) only used non-opioid drugs, in order to

257 focus specifically on opioid drug use; and/or 3) could not provide clear answers to the questions,

258 or did not know or refused to answer questions. Finally, while many variables and potential

259 explanatory factors were controlled for or assessed as confounders it is possible that there are

260 additional unobserved explanatory factors not contained within this analysis.

261 Conclusion

262 Opioid overdoses in Canada continue to be a significant public health crisis and

263 individuals who are unstably housed are extremely susceptible to overdose. Unstably housed

264 individuals who use opioids are more likely to utilize hospital services, which impacts both their

265 individual health and wellness while having significant economic costs on society. These

266 findings highlight the importance of considering Housing First in conjunction with supervised

267 consumption services as an important part of harm reduction for populations made vulnerable

268 through structural inequities as part of the response to the overdose epidemic.

269

270 Declarations

271 Ethics approval and consent to participate

272 Ethics approvals were given by the University of Calgary Conjoint Health Research Ethics

273 Board REB\# REB19-2156. Signed and Informed consent was obtained from all individual

274 participants included in the study.

275 Consent for publication

276 Not Applicable

277 Availability of data and materials 
278 The datasets generated and/or analyzed during the current study are not publicly available due to

279 share ownership with not for profit community-based organizations but may be available from

280 the corresponding author on reasonable request.

\section{Competing interests}

282 The authors declare that they have no competing interests.

\section{Funding}

284 Funding was provided in part by Alberta Health (through a third party grant with the Alberta

285 Community Council on HIV) and Canadian Institutes for Health Research.

\section{Authors' contributions}

287 All authors contributed to the study conception and design. Material preparation, data collection 288 and analysis were performed by Jenna Passi, Lisa Zaretsky, Tong Liu and Daniel Dutton. The 289 first draft of the manuscript was written by Jenna Passi and all authors commented on previous 290 versions of the manuscript. All authors read and approved the final manuscript.

\section{Acknowledgements}

292 The authors would like to thank the Calgary, Medicine Hat and Red Deer Coalition's for 293 Supervised Consumption Services for project oversight, guidance and advice and for their 294 support with recruitment. We would also like to thank our funders. Finally we would like to 295 thank the 813 people who contributed their experiences trying to access supports for health and 296 wellness.

297 


\section{References}

Smith JJ. The world of science. Am J Sci. 1999;36:234-5.

Doe J. Title of subordinate document. In: The dictionary of substances and their effects. Royal Society of Chemistry. 1999. http://www.rsc.org/dose/title of subordinate document. Accessed 15 Jan 1999.

AHS. (Alberta Health Services). FAQs Supervised consumption services. 2016. https://www.albertahealthservices.ca/assets/info/amh/if-amh-supervised-consumptionfaq.pdf. Accessed 20 November 2019.

AHS. (Alberta Health Services). 2020. Safeworks monthly report - May 2020. Supervised consumption sites. $2020 \quad$ https://www.albertahealthservices.ca/assets/info/amh/ifamh-sup-con-chumir-2020- 05.pdf. Accessed 15 September 2020.

Amari E, Rehm J, Goldner E, Fischer B. Nonmedical prescription opioid use and mental health and pain comorbidities: A narrative review. The Canadian Journal of Psychiatry. 2011; 56(8): 495-502.

Baggett TP, Hwang S, O’Connell W, Porneala JJ, Stringfellow $\backslash$ BC, Orav EJ, Rigotti NA. Mortality among homeless adults in Boston: Shifts in causes of death Over a 15-Year period. 2013. JAMA Internal Medicine;173(3): 189-195.

Baggett TP, Chang Y, Singer DE, Porneala BC, Gaeta JM, O’Connell JJ, Rigotti NA. (2015). Tobacco-, alcohol-, and drug-attributable deaths and their contribution to mortality disparities in a cohort of homeless adults in Boston. 2015. American Journal of Public Health;105(6): 1189-1197. doi: 10.2105/AJPH.2014.302248

BC Center for Disease Control. BC public health opioid overdose emergency March 2017 update. 2017. http://www.bccdc.ca/resourcegallery/Documents/Educational\%20Materials/Epid/Other/Public\%20Surveillance\%20Re port_2017_03_17.pdf. Accessed 15 November 2019.

CIHI. (Canadian Institute for Health Information). Opioid-Related Harms in Canada: Report December 2018. 2018.https://www.cihi.ca/sites/default/files/document/opioid-relatedharms-report-2018-en-web.pdf. Accessed 15 November 2019.

Doran KM, Rahai N, McCormack RP, Milian J, Shelley D, Rotrosen J, Gelberg L. Substance use and homelessness among emergency department patients. 2018. Drug and Alcohol Dependence. 188; 328-333.

Gaetz S, Donaldson J, Richter T, Gulliver T. The State of Homelessness in Canada 2013. Toronto: Canadian Homelessness Research Network Press. 2013a. https://www.homelesshub.ca/SOHC2013, Accessed 16 November 2019. 
Gaetz S, Scott F, Gulliver T. Housing First in Canada: Supporting Communities to End Homelessness. Toronto: Canadian Homelessness Research Network Press. 2013b. https://www.homelesshub.ca/sites/default/files/HousingFirstInCanada.pdf. Accessed 16 November 2019.

Galea S, Nandi A, Vlahov D. The social epidemiology of substance use. 2004. Epidemiological Reviews; 26(1):36-52.

Government of Alberta. Alberta opioid response surveillance report: Q4 2019. March 2020. 2020a. https://open.alberta.ca/dataset/f4b74c38-88cb-41ed-aa6f32db93c7c391/resource/1044cc6d-3a29-4f4b-9f96-6264e92e17e0/download/healthalberta-opioid-response-surveillance-report-2019-q4.pdf. Accessed 20 September 2020.

Government of Alberta. Alberta opioid response surveillance report: Q1 2020. June 2020. 2020b. https://open.alberta.ca/dataset/f4b74c38-88cb-41ed-aa6f32db93c7c391/resource/45e03e51-0fa8-49f8-97aa-06b527f7f42c/download/healthalberta-opioid-response-surveillance-report-2020-q1.pdf. Accessed 20 September 2020.

Government of Canada. Government of Canada Federal Actions on Opioids to Date. 2020. https://www.canada.ca/content/dam/hc- sc/documents/services/substanceuse/problematic-prescription-drug- use/opioids/responding-canada-opioidcrisis/federal-actions/june_2020_pager-FINAL_.pdf. Accessed 28 June 2020.

Hwang S. Homelessness and health. 2001. CMAJ;164(1): 229-233

Hwang SW, Chambers C, Chiu S, Katic M, Kiss A, Redelmeier DA, Levinson WA. comprehensive assessment of health care utilization among homeless adults under a system of universal health insurance. 2013. American Journal of Public Health; 103(S2):S294-S301.

Jaworsky D, Gadermann A, Duhoux A, Naismith TE, Norena M, To MJ, Palepu A. Residential stability reduces unmet health care needs and emergency department utilization among a cohort of homeless and vulnerably housed persons in Canada. 2013. Journal of Urban Health; 93(4): 666-681.

Katzenstein, A, Weinstein L, Tice M, Dichter H, Stefancic A, Husayn S, Siddiqui BS, Qais I. 2019. APHA's 2019 Annual Meeting and Expo (Nov. 2 - Nov. 6). https://apha.confex.com/apha/2019/meetingapp.cgi/Session/59178. Accessed 12 June 2020.

Khandor E, Mason K, Chambers C, Rossiter K, Cowan L, Hwang SW. Access to primary health care among homeless adults in Toronto, Canada: results from the Street Health survey. 2011. Open Med; 5(2): e94-103. 
Latimer EZ, Rabouin D, Cao Z, Ly A, Powell G, Aubry T, Goering PN. Costs of services for homeless people with mental illness in 5 Canadian cities: A large prospective follow-up study. 2017. CMAJ Open; 5(3): E576-E585.

Magwood O, Salvalaggio G, Beder MK, Claire K, Victoire D, Daghmach W, Habonimana G, Marshall Z, Snyder E, O’Shea T, Lennox R, Hsu H, Tugwell P, Pottie K. The effectiveness of substance use interventions for homeless and vulnerably housed persons: A systematic review of systematic reviews on supervised consumption facilities, managed alcohol programs, and pharmacological agents for opioid use disorder. 2020 PloS One; 15(1): E0227298. https://doi.org/10.1371/journal.pone.0227298

NHCHC. (National Health Care for the Homeless Council). Addressing the opioid epidemic: How the overdose crisis affects homeless populations. 2017. https://nhchc.org/wp-content/uploads/2019/08/nhchc-opioid-fact-sheet-august-2017.pdf. Accessed 15 June 2020.

Yamamoto A, Needleman J, Gelberg L, Kominski G, Shoptaw S, Tsugawa Y. Association between homelessness and opioid overdose and opioid-related hospital admissions/emergency department visits. 2019. Social Science \& Medicine; 242: 112585. Zivanovic R, Milloy MJ, Hayashi K, Dong H, Sutherland C, Kerr T. Wood E. Impact of unstable housing on all-cause mortality among persons who inject drugs. 2015. BMC Public Health; 15(106). https://doi.org/10.1186/s12889-015-1479-x 
Table 1. Variable Definition and Coding

\begin{tabular}{|c|c|c|}
\hline $\begin{array}{l}\text { Variable of } \\
\text { Interest }\end{array}$ & $\begin{array}{l}\text { Characteristic/Experience Absent } \\
\text { or Infrequent (0) }\end{array}$ & $\begin{array}{l}\text { Characteristic/Experience } \\
\text { Present or Frequent (1) }\end{array}$ \\
\hline \multicolumn{3}{|l|}{ Outcome Variable } \\
\hline Hospital Use & $\begin{array}{l}\text { No - hospital care (overnight or } \\
\text { longer) was not used within the last } \\
12 \text { months due to problems with } \\
\text { emotions, mental health, or alcohol/ } \\
\text { drug use }\end{array}$ & $\begin{array}{l}\text { Yes - hospital care (overnight or } \\
\text { longer) was used within the last } 12 \\
\text { months due to problems with } \\
\text { emotions, mental health, or alcohol/ } \\
\text { drug use }\end{array}$ \\
\hline \multicolumn{3}{|c|}{ S } \\
\hline Housing Unstable & $\begin{array}{l}\text { No-did not identify as housing } \\
\text { unstable }\end{array}$ & $\begin{array}{l}\text { Yes - identified as housing } \\
\text { unstable }\end{array}$ \\
\hline Sex & Male participants & Female participants \\
\hline Indigenous Status & Non-Indigenous participants & $\begin{array}{l}\text { Indigenous participants (First } \\
\text { Nations, Metis, Inuit) }\end{array}$ \\
\hline Age (real age) & Participants entered age in years & \\
\hline Location & Calgary & Medicine Hat or Red Deer \\
\hline \multicolumn{3}{|c|}{ Characteristics of Drug Use } \\
\hline Had an overdose & $\begin{array}{l}\text { No - did not overdose within past } 6 \\
\text { months }\end{array}$ & $\begin{array}{l}\text { Yes - did overdose within past } 6 \\
\text { months }\end{array}$ \\
\hline $\begin{array}{l}\text { How often: } \\
\text { polydrug use }\end{array}$ & $\begin{array}{l}\text { Used more than } 1 \text { type of drug on } \\
\text { the same occasion } 2 \text { to } 4 \text { times a } \\
\text { month or less }\end{array}$ & $\begin{array}{l}\text { Used more than } 1 \text { type of drug on } \\
\text { the same occasion } 2 \text { to } 3 \text { times a } \\
\text { week or more }\end{array}$ \\
\hline $\begin{array}{l}\text { How often: } \\
\text { heavily } \\
\text { influenced by } \\
\text { drugs }\end{array}$ & $\begin{array}{l}\text { Over the past year, are influenced } \\
\text { heavily by drugs other than alcohol } \\
\text { on a monthly basis or less }\end{array}$ & $\begin{array}{l}\text { Over the past year, are influenced } \\
\text { heavily by drugs other than alcohol } \\
\text { on a weekly basis or more }\end{array}$ \\
\hline $\begin{array}{l}\text { How often: } \\
\text { irresistible } \\
\text { longing to use }\end{array}$ & $\begin{array}{l}\text { Over the past year, you felt you had } \\
\text { a longing to use drugs so strong } \\
\text { that you could not resist on a } \\
\text { monthly basis or less }\end{array}$ & $\begin{array}{l}\text { Over the past year, you felt you had } \\
\text { a longing to use drugs so strong } \\
\text { that you could not resist on a } \\
\text { weekly basis or more }\end{array}$ \\
\hline $\begin{array}{l}\text { How often: } \\
\text { unable to stop use }\end{array}$ & $\begin{array}{l}\text { Over the past year, you have not } \\
\text { been able to stop taking drugs once } \\
\text { you started on a monthly basis or } \\
\text { less }\end{array}$ & $\begin{array}{l}\text { Over the past year, you have not } \\
\text { been able to stop taking drugs once } \\
\text { you started on a weekly basis or } \\
\text { more }\end{array}$ \\
\hline $\begin{array}{l}\text { How often: } \\
\text { neglected tasks } \\
\text { due to use }\end{array}$ & $\begin{array}{l}\text { Over the past year, you have } \\
\text { neglected to do something you } \\
\text { should have due to having used } \\
\text { drugs on a monthly basis or less }\end{array}$ & $\begin{array}{l}\text { Over the past year, you have } \\
\text { neglected to do something you } \\
\text { should have due to having used } \\
\text { drugs on a weekly basis or more }\end{array}$ \\
\hline $\begin{array}{l}\text { How often: need } \\
\text { to use in morning }\end{array}$ & $\begin{array}{l}\text { Over the past year, you have } \\
\text { needed to use in the morning after } \\
\text { heavy drug use the day before on a } \\
\text { monthly basis or less }\end{array}$ & $\begin{array}{l}\text { Over the past year, you have } \\
\text { needed to use in the morning after } \\
\text { heavy drug use the day before on a } \\
\text { weekly basis or more }\end{array}$ \\
\hline
\end{tabular}


Table 1. Variable Definition and Coding

\begin{tabular}{|c|c|c|}
\hline $\begin{array}{l}\text { Variable of } \\
\text { Interest }\end{array}$ & $\begin{array}{l}\text { Characteristic/Experience Absent } \\
\text { or Infrequent (0) }\end{array}$ & $\begin{array}{l}\text { Characteristic/Experience } \\
\text { Present or Frequent (1) }\end{array}$ \\
\hline $\begin{array}{l}\text { How often: feel } \\
\text { guilty due to drug } \\
\text { use }\end{array}$ & $\begin{array}{l}\text { Over the past year, you have had } \\
\text { guilty feelings or a bad conscience } \\
\text { because you used drugs on a } \\
\text { monthly basis or less }\end{array}$ & $\begin{array}{l}\text { Over the past year, you have had } \\
\text { guilty feelings or a bad conscience } \\
\text { because you used drugs on a } \\
\text { weekly basis or more }\end{array}$ \\
\hline Hurt due to use & $\begin{array}{l}\text { No - you or others have not been } \\
\text { hurt (mentally or physically) due to } \\
\text { your drug use }\end{array}$ & $\begin{array}{l}\text { Yes - you or others have been hurt } \\
\text { (mentally or physically) due to your } \\
\text { drug use }\end{array}$ \\
\hline $\begin{array}{l}\text { Others worry due } \\
\text { to use }\end{array}$ & $\begin{array}{l}\text { No - relatives, friends, or medical } \\
\text { professionals have not been worried } \\
\text { about your drug use or said you } \\
\text { should stop using }\end{array}$ & $\begin{array}{l}\text { Yes - relatives, friends, or medical } \\
\text { professionals have been worried } \\
\text { about your drug use or said you } \\
\text { should stop using }\end{array}$ \\
\hline \multicolumn{3}{|c|}{ Health Characteristics } \\
\hline $\begin{array}{l}\text { Diagnosed with } \\
\text { addiction or } \\
\text { mental health } \\
\text { disorder }\end{array}$ & $\begin{array}{l}\text { No - health professional has not } \\
\text { diagnosed you with an addiction or } \\
\text { mental health disorder }\end{array}$ & $\begin{array}{l}\text { Yes - health professional has } \\
\text { diagnosed you with an addiction or } \\
\text { mental health disorder }\end{array}$ \\
\hline \multicolumn{3}{|c|}{ Adequacy of Non-Hospital Services } \\
\hline $\begin{array}{l}\text { Inadequate: Could } \\
\text { not access }\end{array}$ & $\begin{array}{l}\text { Reported no problem accessing } \\
\text { health care services that were } \\
\text { perceived as needed. Services } \\
\text { include: information about medical } \\
\text { treatment, medication or tablets, } \\
\text { counselling outside of a hospital, } \\
\text { social interventions, skills training, } \\
\text { harm reduction services, and } \\
\text { medical care for physical health. }\end{array}$ & $\begin{array}{l}\text { Reported needing a service but was } \\
\text { unable to access the service. }\end{array}$ \\
\hline $\begin{array}{l}\text { Inadequate: Did } \\
\text { not receive } \\
\text { enough }\end{array}$ & $\begin{array}{l}\text { Reported no problem with } \\
\text { accessing enough of the health care } \\
\text { services listed above, either due to } \\
\text { adequate amounts or not requiring } \\
\text { them. . }\end{array}$ & $\begin{array}{l}\text { Reported needing more of a } \\
\text { service but was unable to access the } \\
\text { amount required. }\end{array}$ \\
\hline
\end{tabular}

400 Table 2. Sample Characteristics by Hospital Use with Pearson Chi-Squared Results (n=432)

\begin{tabular}{|c|c|c|c|c|}
\hline \multirow[b]{2}{*}{ Characteristic } & \multirow[b]{2}{*}{ Total n (\%) } & \multicolumn{2}{|c|}{ Hospital Use } & \\
\hline & & $\begin{array}{l}\text { Yes } 183 \\
(42.4 \%)\end{array}$ & $\begin{array}{l}\text { No } 249 \\
(57.6 \%)\end{array}$ & p-value \\
\hline
\end{tabular}




\begin{tabular}{|c|c|c|c|c|}
\hline \multirow[b]{2}{*}{ Characteristic } & \multirow[b]{2}{*}{ Total n (\%) } & \multicolumn{2}{|c|}{ Hospital Use } & \multirow[b]{2}{*}{ p-value } \\
\hline & & $\begin{array}{l}\text { Yes } 183 \\
(42.4 \%)\end{array}$ & $\begin{array}{l}\text { No 249 } \\
(57.6 \%)\end{array}$ & \\
\hline Yes & $240(55.6)$ & $124(67.8)$ & $116(46.6)$ & $<0.001$ \\
\hline No & $192(44.4)$ & $59(32.2)$ & $133(53.4)$ & \\
\hline \multicolumn{5}{|l|}{ Sex } \\
\hline Female & $150(34.7)$ & $62(33.9)$ & $88(35.3)$ & 0.753 \\
\hline Male & $282(65.3)$ & $121(66.1)$ & $161(64.7)$ & \\
\hline \multicolumn{5}{|l|}{ Indigenous Status } \\
\hline Indigenous & $141(32.6)$ & $66(36.1)$ & $75(30.1)$ & 0.193 \\
\hline Non-Indigenous & $291(67.4)$ & $117(63.9)$ & $174(69.9)$ & \\
\hline Age, in years (range)* & $37.4(16-68)$ & 36.3 & 38.2 & 0.117 \\
\hline \multicolumn{5}{|l|}{ Location } \\
\hline Medicine Hat or Red Deer & $224(51.9)$ & $98(53.6)$ & $139(55.8)$ & 0.054 \\
\hline Calgary & $208(48.1)$ & $85(46.4)$ & $110(44.2)$ & \\
\hline \multicolumn{5}{|l|}{ Drug Use Characteristics } \\
\hline \multicolumn{5}{|l|}{ Had an overdose } \\
\hline Yes & $137(31.7)$ & $89(48.6)$ & $48(19.3)$ & $<0.001$ \\
\hline No & $295(68.3)$ & $94(51.4)$ & $201(80.7)$ & \\
\hline \multicolumn{5}{|l|}{ How often: polydrug use } \\
\hline 2-3x/Week or More & $233(53.9)$ & $114(62.3)$ & $119(47.8)$ & 0.003 \\
\hline $2-4 \mathrm{x} /$ Month or Less & $199(46.1)$ & $69(37.7)$ & $130(52.2)$ & \\
\hline \multicolumn{5}{|c|}{$\begin{array}{l}\text { How often: heavily influenced by } \\
\text { drugs }\end{array}$} \\
\hline Weekly or Daily & $333(77.1)$ & $152(83.1)$ & $181(72.7)$ & 0.011 \\
\hline
\end{tabular}




\begin{tabular}{|c|c|c|c|c|}
\hline \multirow[b]{2}{*}{ Characteristic } & \multirow[b]{2}{*}{ Total n $(\%)$} & \multicolumn{2}{|c|}{ Hospital Use } & \multirow[b]{2}{*}{ p-value } \\
\hline & & $\begin{array}{l}\text { Yes } 183 \\
(42.4 \%) \\
\end{array}$ & $\begin{array}{l}\text { No } 249 \\
(57.6 \%)\end{array}$ & \\
\hline Monthly or Less & $99(22.9)$ & $31(16.9)$ & $68(27.3)$ & \\
\hline \multicolumn{5}{|c|}{$\begin{array}{l}\text { How often: irresistible longing to } \\
\text { use }\end{array}$} \\
\hline Weekly or Daily & $261(60.4)$ & $121(66.1)$ & $140(56.2)$ & 0.038 \\
\hline Monthly or Less & $171(39.6)$ & $62(33.9)$ & $109(43.8)$ & \\
\hline \multicolumn{5}{|c|}{ How often: unable to stop use } \\
\hline Weekly or Daily & $248(57.4)$ & $113(61.7)$ & $135(54.2)$ & 0.118 \\
\hline Monthly or Less & $184(42.6)$ & $70(38.3)$ & $114(45.8)$ & \\
\hline \multicolumn{5}{|c|}{$\begin{array}{l}\text { How often: neglected tasks due to } \\
\text { use }\end{array}$} \\
\hline Weekly or Daily & $273(63.2)$ & $140(76.5)$ & $133(53.4)$ & $<0.001$ \\
\hline Monthly or Less & $159(36.8)$ & $43(23.5)$ & $116(46.6)$ & \\
\hline \multicolumn{5}{|c|}{$\begin{array}{l}\text { How often: need to use in } \\
\text { morning }\end{array}$} \\
\hline Weekly or Daily & $291(67.4)$ & $137(74.9)$ & $154(61.8)$ & 0.004 \\
\hline Monthly or Less & $141(32.6)$ & $46(25.1)$ & $95(38.2)$ & \\
\hline \multicolumn{5}{|c|}{$\begin{array}{l}\text { How often: feel guilty due to drug } \\
\text { use }\end{array}$} \\
\hline Weekly or Daily & $313(72.5)$ & $143(78.1)$ & $170(68.3)$ & 0.023 \\
\hline Monthly or Less & $119(27.5)$ & $40(21.9)$ & $79(31.7)$ & \\
\hline \multicolumn{5}{|l|}{ Hurt due to use } \\
\hline Yes & $359(83.1)$ & $160(87.4)$ & 199 (79.9) & 0.040 \\
\hline No & $73(16.9)$ & $23(12.6)$ & $50(20.1)$ & \\
\hline \multicolumn{5}{|c|}{ Others worry due to use } \\
\hline Yes & $370(85.6)$ & $167(91.3)$ & $203(81.5)$ & 0.040 \\
\hline
\end{tabular}




\begin{tabular}{|c|c|c|c|c|}
\hline \multirow[b]{2}{*}{ Characteristic } & \multirow[b]{2}{*}{ Total n (\%) } & \multicolumn{2}{|c|}{ Hospital Use } & \multirow[b]{2}{*}{ p-value } \\
\hline & & $\begin{array}{l}\text { Yes } 183 \\
(42.4 \%)\end{array}$ & $\begin{array}{l}\text { No } 249 \\
(57.6 \%)\end{array}$ & \\
\hline No & $62(14.4)$ & $16(8.7)$ & $46(18.5)$ & \\
\hline \multicolumn{5}{|c|}{ Health Characteristics } \\
\hline \multicolumn{5}{|c|}{$\begin{array}{l}\text { Diagnosed with addiction or mental health } \\
\text { disorder }\end{array}$} \\
\hline Yes & $351(81.2)$ & $162(88.5)$ & 189 (75.9) & 0.001 \\
\hline No & $81(18.8)$ & $21(11.5)$ & $60(24.1)$ & \\
\hline \multicolumn{5}{|c|}{ Experience of Receiving Services } \\
\hline \multicolumn{5}{|c|}{ Inadequate Access } \\
\hline Yes & $238(55.1)$ & $113(61.7)$ & $125(50.2)$ & 0.017 \\
\hline No & $194(44.9)$ & $70(38.3)$ & $124(49.8)$ & \\
\hline \multicolumn{5}{|c|}{ Inadequate Amount } \\
\hline Yes & $246(56.9)$ & $109(59.6)$ & $137(55.0)$ & 0.346 \\
\hline No & $186(43.1)$ & $74(40.4)$ & $112(45.0)$ & \\
\hline
\end{tabular}

$401 \quad$ *p-value for age is a two-tailed t-test.

402

403 Table 3. Logistic Regression onto Hospital Use (N=432)

404

405 


\begin{tabular}{|c|c|c|c|c|c|c|}
\hline & \multicolumn{3}{|c|}{ Unadjusted } & \multicolumn{3}{|c|}{ Adjusted } \\
\hline & $\mathbf{O R}$ & $95 \% \mathrm{CI}$ & $\begin{array}{c}\text { p- } \\
\text { value }\end{array}$ & OR & $95 \% \mathrm{CI}$ & $\begin{array}{c}\text { p- } \\
\text { value }\end{array}$ \\
\hline $\begin{array}{l}\text { Housing Unstable } \\
(1=\text { Yes })\end{array}$ & 2.409 & $\begin{array}{l}1.619- \\
3.586\end{array}$ & 0.000 & 2.035 & $\begin{array}{l}1.289- \\
3.214\end{array}$ & 0.002 \\
\hline $\begin{array}{l}\text { Sex } \\
(1=\text { Female })\end{array}$ & 0.937 & $\begin{array}{c}0.627- \\
1.400\end{array}$ & 0.753 & 0.055 & $\begin{array}{l}0.006- \\
0.474\end{array}$ & 0.008 \\
\hline $\begin{array}{l}\text { Indigenous Status } \\
(1=\text { Indigenous })\end{array}$ & 1.319 & $\begin{array}{c}0.873- \\
1.963\end{array}$ & 0.193 & 1.221 & $\begin{array}{c}0.757- \\
1.968\end{array}$ & 0.413 \\
\hline $\begin{array}{l}\text { Location } \\
\text { (1 = Medicine Hat or Red Deer) }\end{array}$ & 0.686 & $\begin{array}{c}0.468- \\
1.007\end{array}$ & 0.054 & 0.669 & $\begin{array}{c}0.429- \\
1.046\end{array}$ & 0.078 \\
\hline $\begin{array}{l}\text { Had an overdose } \\
(1=\text { Yes })\end{array}$ & 3.965 & $\begin{array}{l}2.584- \\
6.083\end{array}$ & $<0.001$ & 3.586 & $\begin{array}{l}2.206- \\
5.829\end{array}$ & $<0.001$ \\
\hline $\begin{array}{l}\text { How often: polydrug use } \\
(1=2-3 \text { times/week or more })\end{array}$ & 1.801 & $\begin{array}{l}1.223- \\
2.663\end{array}$ & 0.003 & 1.108 & $\begin{array}{c}0.675- \\
1.819\end{array}$ & 0.684 \\
\hline $\begin{array}{l}\text { How often: heavily influenced by } \\
\text { drugs }\end{array}$ & 1.842 & $\begin{array}{l}1.144- \\
2.966\end{array}$ & 0.012 & 1.298 & $\begin{array}{l}0.722- \\
2.330\end{array}$ & 0.383 \\
\hline$(1=$ Weekly or Daily $)$ & & & & & & \\
\hline $\begin{array}{l}\text { How often: irresistible longing to } \\
\text { use } \\
(1=\text { Weekly or Daily })\end{array}$ & 1.519 & $\begin{array}{l}1.023- \\
2.257\end{array}$ & 0.038 & 0.753 & $\begin{array}{c}0.418- \\
1.359\end{array}$ & 0.347 \\
\hline $\begin{array}{l}\text { How often: unable to stop use } \\
(1=\text { Weekly or Daily) }\end{array}$ & 1.363 & $\begin{array}{l}0.924- \\
2.011\end{array}$ & 0.118 & 0.767 & $\begin{array}{c}0.439- \\
1.338\end{array}$ & 0.350 \\
\hline $\begin{array}{l}\text { How often: neglected tasks due to } \\
\text { use } \\
(1=\text { Weekly or Daily) }\end{array}$ & 2.839 & $\begin{array}{l}1.861- \\
4.334\end{array}$ & $<0.001$ & 2.187 & $\begin{array}{l}1.284- \\
3.726\end{array}$ & 0.004 \\
\hline $\begin{array}{l}\text { How often: feel guilty due to drug } \\
\text { use } \\
(1=\text { Weekly or Daily) }\end{array}$ & 1.661 & $\begin{array}{l}1.069- \\
2.581\end{array}$ & 0.024 & 1.094 & $\begin{array}{c}0.637- \\
1.878\end{array}$ & 0.745 \\
\hline Others worry due to use & 2.365 & $\begin{array}{l}1.292- \\
4.329\end{array}$ & 0.005 & 1.728 & $\begin{array}{c}0.850- \\
3.511\end{array}$ & 0.131 \\
\hline
\end{tabular}


(1=Yes)

$\begin{array}{lllllll}\text { Diagnosed addiction or mental } & 2.449 & 1.428- & 0.001 & 1.262 & 0.634- & 0.508\end{array}$ health concern

(1= Weekly or Daily)

Inadequate Access

(1=Yes)

$1.601 \quad 1.086-\quad 0.017 \quad 1.283 \quad 0.815-\quad 0.282$

2.361

2.021

Inadequate Amount

1.2040 .818

0.346

1.000

0.638

0.999

(1=Yes)

1.773

1.569

Sex*Diagnosed

$1.331 \quad 0.879-$

0.177

22.433

2.466

0.006

2.015 204.064

Constant

0.001

$<0.001$

406 